\title{
PENGARUH FIRM SIZE DAN GROWTH OPPORTUNITY TERHADAP CASH HOLDING DAN FIRM VALUE
}

\author{
Luh Putu Erma Liestyasih ${ }^{1}$ \\ Luh Putu Wiagustini ${ }^{2}$ \\ ${ }^{1,2}$ Fakultas Ekonomi dan Bisnis Universitas Udayana, Bali, Indonesia \\ e-mail: liestyasiherma@gmail.com
}

\begin{abstract}
ABSTRAK
Penelitian ini memiliki tujuan mengetahui pengaruh firm size dan growth opportunity terhadap cash holding dan firm value. Perusahaan sektor manufaktur yang tercatat di Bursa Efek Indonesia merupakan populasi penelitian dan sebanyak 38 perusahaan dipilih sebagai sampel dengan metode purposive sampling. Data penelitian merupakan data sekunder dari tahun 2013 sampai dengan tahun 2016. Analisis jalur (path analysis) digunakan sebagai teknik pengujian hipotesis penelitian, dengan aplikasi SPSS. Hasil penelitian menunjukkan: firm size dan growth opportunity berpengaruh positif signifikan pada firm value. Firm size berpengaruh negatif signifikan pada cash holding. Growth opportunity berpengaruh positif signifikan pada cash holding. Cash holding berpengaruh positif signifikan pada firm value. Cash holding mampu memediasi pengaruh growth opportunity terhadap firm value.
\end{abstract}

Kata kunci: firm size, growth opportunity, cash holding, dan firm value.

\section{ABSTRACT}

This research aims to determine the effect of firm size and growth opportunity to cash holding and firm value. Manufacturing companies that listed in Indonesian Stock Exchange are used as population. Annual financial data of 38 firms from manufacturing companies listed on Indonesian Stock Exchange from 2013 to 2016 examined as sample. Path analysis technique used to analysis hypothesis of the research by SPSS software. The results showed that: firm size and growth opportunity had positive and significant impact on firm value. Firm size had negative and significant impact on cash holding. Growth opportunity had positive and significant impact on cash holding. Cash holding had positive and significant impact on firm value. Cash holding mediated the effect of growth opportunity on firm value significantly.

Keywords: firm size, growth opportunity, cash holding, and firm value. 


\section{PENDAHULUAN}

Menurut pandangan manajemen keuangan mengoptimalkan nilai perusahaan merupakan tujuan utama dari perusahaan (Hardiningsih, 2009). Bagi perusahaan memaksimumkan nilai perusahaan memiliki arti yang penting, karena dengan maksimumnya nilai perusahaan berarti bahwa kesejahteraan pemegang saham juga maksimum. Menurut Putu et al. (2014), nilai perusahaan merupakan faktor penting yang harus diidentifikasi investor sebelum melakukan investasi. Nilai perusahaan dianggap sebagai hal yang krusial karena menggambarkan kemakmuran pemilik perusahaan (Hidayah, 2014). Pemegang saham sebagai pemilik perusahaan memiliki kemampuan untuk memilih direktur dan mempekerjakan manajer (Brigham \& Daves, 2010: 4). Manajer sebagai perwakilan perusahaan, bertanggung jawab untuk mencapai nilai perusahaan yang optimal, berdasarkan hal itu maka manajemen perusahaan harus menjalankan perusahaan berdasarkan kepentingan pemegang saham dan menjalankan kebijakan untuk meningkatkan nilai dari pemegang saham.

Fanani \& Hendrick (2016) menyatakan nilai perusahaan menunjukkan bagaimana pasar menilai perusahaan secara keseluruhan. Firm value merupakan gambaran dari kepercayaan masyarakat terhadap keberhasilan kinerja manajemen perusahaan. Pada perusahaan go public, nilai perusahaan akan tercermin dari harga saham di pasar modal. Besarnya firm value dapat dipengaruhi oleh firm size (Hermuningsih, 2012), growth opportunity (Pangulu \& Maski, 2015) dan cash holding (Kerryanto, 2015). 
Firm size adalah gambaran dari besar kecilnya ukuran sebuah perusahaan. Perusahaan dengan ukuran besar dianggap lebih mampu meningkatkan nilai perusahaan, karena manajemen memiliki keleluasaan dalam menggunakan aset perusahaan untuk meningkatkan produktivitas (Saputra \& Fachrurrozie, 2015). Firm size merupakan salah satu faktor penting bagi investor maupun kreditor sebelum melakukan investasi, hal ini karena firm size berhubungan dengan risiko dari investasi (Moeljadi, 2014).

Growth opportunity adalah probabilitas perusahaan untuk tumbuh di masa depan (Mai, 2006 dalam Hermuningsih, 2013). Growth opportunity yang semakin meningkat akan dilihat oleh investor sebagai sinyal yang baik bagi pertumbuhan perusahaan di masa depan. Hal ini menandakan bahwa perkembangan perusahaan dianggap sebagai tanda dari adanya aspek yang menguntungkan dengan harapan memperoleh pengembalian investasi yang lebih baik oleh investor.

Penelitian mengenai nilai perusahaan sudah sering dilakukan namun masih menemukan hasil yang berbeda-beda. Penelitian Hermuningsih (2012) mengenai firm size yang menemukan firm size berpengaruh positif signifikan pada nilai perusahaan, tetapi Saputra \& Fachrurrozie (2015), menemukan hubungan positif tidak signifikan antara firm size dengan nilai perusahaan. Fanani \& Hendrick (2016) dalam penelitiannya menemukan tidak terdapat hubungan antara firm size dan nilai perusahaan. Penelitian tentang variabel growth opportunity yang dilakukan oleh Pangulu \& Maski, (2015) menemukan pengaruh positif antara growth opportunity denagn nilai perusahaan. Perbedaan hasil penelitian 
dikemukakan Suwarno, dkk (2016) yang menemukan pengaruh positif tidak signifikan antara growth opportunity dengan nilai perusahaan.

Kariuki et al. (2015) dalam penelitiannya tentang variabel firm size menemukan pengaruh yang positif signifikan antara firm size dengan cash holding, tetapi penelitian Ogundipe et al. (2012) menemukan firm size berpengaruh positif tidak signifikan pada cash holding. Penelitian mengenai varibael growth opportunity oleh William \& Fauzi (2013) menemukan growth opportunity berpengaruh positif signifikan pada cash holding, sedangkan penelitian Kerryanto (2015) serta Fanani \& Hendrick (2016) mengenai cash holding menemukan cash holding berpengaruh positif signifikan pada nilai perusahaan.

Ketidakkonsistenan hasil penelitian sebelumnya mengenai pengaruh firm size dan growth opportunity terhadap firm value merupakan alasan melakukan penelitian ini dengan menambahkan cash holding sebagai variabel mediasi. Cash holding diharapkan mampu memediasi pengaruh firm size dan growth opportunity pada nilai perusahaan dikarenakan ditemukan pengaruh yang positif antara firm size dan growth opportunity dengan cash holding serta nilai perusahaan.

Kas merupakan aset likuid dimana kepemilikan kas selalu melibatkan tradeoff antara manfaat dan biaya. Kas memiliki fungsi penting untuk menjalankan operasi perusahaan sehingga tanpa kas perusahaan akan sulit untuk mempertahankan operasinya dan pengambilan keputusan tentang cash holding menjadi salah satu perhatian utama seorang manajer. Cash holding menurut Gill 
dan Shah (2012) merupakan kas ditangan atau tersedia untuk dibagikan kepada investor.

Penelitian Bates et al. (2009) menemukan cash holding pada perusahaan di Amerika mengalami kenaikan dari tahun 1980-2006, ditemukan bahwa rata-rata rasio kas mengalami peningkatan sebesar 0,46 persen per tahunnya, atau dapat dikatakan bahwa terjadi peningkatan cash holding dua kali lipat pada tahun 1980 sebesar 10,5 persen menjadi 23,2 persen pada 2006. Datta dan Jia (2012) juga menemukan bahwa cash holding mengalami tren kenaikan pada perusahaanperusahaan di Kanada, Prancis, Amerika Serikat, Inggris dan Jerman, tetapi hal yang sebaliknya justru terjadi di Jepang. Meningkatnya jumlah cash holding pada perusahaan menunjukkan bahwa perusahaan berusaha untuk menjaga likuiditasnya, sehingga perusahaan akan mampu bertahan saat terjadi krisis.

Terjadinya krisis keuangan menyebabkan perusahaan kesulitan dalam mendapatkan modal eksternal, seperti ketika terjadi krisis pada tahun 2008, yaitu terjadinya krisis ekonomi global akibat adanya krisis ekonomi Amerika Serikat yang akhirnya menyebar ke berbagai negara termasuk Indonesia (Setiawati \& Ika, 2012). Indonesia memiliki ketergantungan yang tinggi terhadap investor asing, akibat krisis tersebut para investor asing menarik dananya dari Indonesia (Sriwardiningsih, 2010). Hal ini mengakibatkan jatuhnya nilai rupiah, aliran dana asing untuk operasional perusahaan hilang, dan akibatnya banyak perusahaan mengalami kerugian, sehingga hal ini menyebabkan kepemilikan cadangan kas menjadi sangat penting bagi perusahaan. Cadangan kas perusahaan menurut Nhan 
\& Ha (2016) adalah faktor yang akan memengaruhi nilai perusahaan, karena kas serta setara kas digunakan untuk mengoperasikan seluruh aktivitas perusahaan.

Kim et al. (2011) menjelaskan bahwa perusahaan akan meningkatkan cash holding-nya untuk meminimalkan risiko terjadinya kesulitan keuangan, kebangkrutan, dan ancaman default. Cash holding juga dapat menjadi biaya, ketika terdapat kelebihan kas yang dialokasikan secara tidak efisien oleh manager pada proyek yang dapat menurunkan nilai perusahaan (value-destroying projects). Managemen selaku agen dari para shareholder harus mengalokasikan cash holding optimal dengan prinsip bahwa cash holding akan mampu memberikan manfaat bagi kesejahteraan pemegang saham (Opler et al., 1999).

Firm size akan berpengaruh terhadap tingkat cash holding perusahaan karena perusahaan akan berusaha menjaga tingkat operasi dan investasinya (Gomes, 2012). Perusahaan yang lebih besar memiliki kemampuan untuk menjaga tingkat cash holding-nya dalam jumlah yang besar, sehingga dapat digunakan untuk cadangan saat terjadi kejadian yang tidak terduga di masa depan.

Growth opportunity akan meningkatkan cash holding perusahaan, karena semakin tinggi kesempatan untuk tumbuh sebuah perusahaan semakin tinggi pula kesempatan mendapatkan return yang lebih besar, sehingga semakin tinggi kemampuan perusahaan untuk mempertahankan kas sebagai pemenuh kebutuhan investasi dimasa depan.

Perusahaan dituntut untuk memiliki fleksibilitas dalam menghadapi berbagai perubahan pada lingkungan eksternal yang mengancam perusahaan. Kemampuan perusahaan dalam bertahan saat terjadi perubahan seperti krisis 
menandakan kemampuan manajer keuangan dalam beradaptasi dan menunjukkan konsistensi manajer dalam mencapai tujuan utama perusahaan. Perusahaan industri sektor manufaktur dipilih karena memiliki kondisi yang cukup stabil bahkan menjadi salah satu sektor penopang perekonomian ditengah ketidakpastian iklim perekonomian dunia (www.kemenperin.go.id).

Adapapun rumusan masalah penelitian: (1) apakah firm size dan growth opportunity berpengaruh signifikan terhadap firm value?. (2) apakah firm size dan growth opportunity berpengaruh signifikan pada cash holding?. (3) apakah cash holding berpengaruh signifikan pada firm value?. (4) pakah firm size dan growth opportunity berpengaruh signifikan terhadap firm value melalui cash holding?.

Tujuan penelitian ini, yaitu: (1) untuk menganalisis signifikansi pengaruh firm size serta growth opportunity terhadap firm value. (2) untuk menganalisis signifikansi pengaruh firm size serta growth opportunity terhadap cash holding. (3) untuk menganalisis signifikansi pengaruh cash holding terhadap firm value. (4) untuk menganalisis signifikansi pengaruh firm size dan growth opportunity terhadap firm value melalui cash holding.

\section{LANDASAN TEORI DAN HIPOTESIS}

\section{Nilai Perusahaan}

Terdapat tujuh "goals" dari perusahaan yaitu, bertahan hidup, menghindari tekanan keuangan dan kebangkrutan, menghindari persaingan, memaksimumkan penjualan dan market share, minimisasi biaya, memaksimumkan keuntungan dan pertumbuhan pendapatan, tetapi tujuan utama dari perusahaan adalah memaksimalkan firm value serta kemakmuran pemegang saham (Kamludin dan 
Luh Putu Erma Liestyasih, dan Luh Putu Wiagustini. Pengaruh Firm Size dan Growth...

Indriani, 2011: 4). Nilai perusahaan merupakan ukuran keberhasilan kinerja manajemen. Shareholder merupakan pemiliki perusahaan, yang mampekerjakan direktur dan manajer, oleh sebab itu manajemen perusahaan harus menjalankan perusahaan berdasarkan kepentingan pemegang saham dan menjalankan kebijakan untuk meningkatkan nilai dari pemegang saham (Brigham \& Daves, 2010: 4).

\section{Signaling Theory}

Signaling theory menjelaskan bagaimana perusahaan seharusnya memberikan sinyal pada investor maupun kreditor tentang apa yang telah dilaksanakan manajemen dalam merealisasikan keinginan investor. Menurut Brigham \& Daves (2010: 532) signaling theory menjelaskan tentang bagaimana manajemen bertindak dalam memberikan petunjuk bagi investor tentang kondisi perusahaan.

\section{Trade-off Theory}

Trade-off theory menilai jika cash holding optimal diperoleh dengan cara mempertimbangkan biaya yang dtimbulkan dengan manfaat yang akan diperoleh dari memegang kas (Herijanto dan Budisantosa, 2016). Manfaat utama memegang kas yang dapat diperoleh perusahaan yaitu, memperkecil kemungkinan timbulnya financial distres, terpenuhinya kebijakan investasi, dan mengurangi terjadinya likuidasi aset.

\section{Pecking Order Theory}

Pecking order theory menjelaskan tentang pemilihan alternatif sumber pembiayaan perusahaan, dimana dijelaskan dalam teori ini bahwa penggunaan sumber dana internal (laba ditahan dan cash holding) menjadi pilihan utama 
perusahaan. Kas disebut berperan sebagai penyangga antara laba ditahan dengan kebutuhan investasi, sehingga saat laba ditahan serta kas tidak lagi mencukupi maka barulah digunakan pembiayaan eksternal.

\section{Manajemen Kas}

Cash management memiliki tujuan untuk memaksimalkan aliran kas masuk dan keluar serta pengeinvestasian kelebihan kas. Seorang manajer keuangan harus mampu menentukan kas optimal, sehingga dapat memenuhi kebutuhan kas untuk kegiatan operasioanl dan cukup untuk memenuhi kebutuhan kas yang tidak terduga. Kariuki et al. (2015) menjelaskan terdapat empat alasan utama perusahaan memiliki cash holding, yaitu: the transaction motive, the precautionary motive, the speculative motive, dan the tax motive.

\section{Cash Holding}

Kamaludin dan Indriani (2012:123) menjelaskan kas sebagai modal kerja yang memiliki sifat paling likuid dibandingkan dengan aset lainnya. Cash holding bermanfaat untuk menghindari terjadinya likuidasi aset, untuk pembiayaan investasi, dibagikan sebagai dividen serta digunakan sebagai cadangan untuk kejadian yang tidak terduga. Penentuan tingkat cash holding menjadi salah satu issue penting dalam pembuatan keputusan perusahaan yang harus diambil manajer keuangan.

\section{Hipotesis Penelitian}

\section{Pengaruh Firm Size dan Growth Opportunity terhadap Nilai Perusahaan}

Firm size yang dilihat dari total aset menunjukkan prospek perusahaan yang bagus dimasa depan karena memiliki aliran kas yang baik serta dianggap lebih 
Luh Putu Erma Liestyasih, dan Luh Putu Wiagustini. Pengaruh Firm Size dan Growth...

stabil serta lebih mampu menghasilkan profit dari pada perusahaan kecil (Moeljadi, 2014). Hal ini akan berakibat pada tingginya harga saham dan sesuai dengan signaling theory, yang menjelasakan perusahaan dengan ukuran besar akan memberikan sinyal positif kepada investor dan lebih menarik bagi investor karena dianggap lebih stabil serta lebih mampu memberikan dividen dimasa depan. Penelitiaan Hermuningsih (2012), Hidayah (2014), serta Novari dan Lestari (2016) menemukan ukuran perusahaan berpengaruh positif signifikan dengan nilai perusahaan.

$\mathrm{H}_{1 . \mathrm{a}}$ : Firm size berpengaruh positif signifikan pada firm value.

Terciptanya kegiatan investasi akan meningkatkan harapan investor untuk memperoleh tingkat return yang semakin tinggi (Pangulu \& Maski, 2015). Terdapatnya peluang investasi pada perusahaan menunjukkan sinyal yang positif bagi investor mengenai adanya pertumbuhan perusahaan di masa depan, yang secara tidak langsung berpengaruh terhadap nilai perusahaan. Hermuningsih (2013), Pangulu \& Maski (2015), Tikawati (2016), dan Andawasatya et al. (2017) menemukan pengaruh positif signifikan antara growth opportunity dengan firm value.

$\mathrm{H}_{1 . \mathrm{b}}$ : Growth opportunity berpengaruh positif signifikan pada firm value.

\section{Pengaruh Firm Size dan Growth Opportunity terhadap Cash holding}

Semakin besar ukuran sebuah perusahaan maka semakin mampu perusahaan untuk menimbun kas dikarenakan perusahaan besar dianggap telah mampu mencapai keberhasilan di masa lalu (Kariuki et al., 2015). Pecking order theory memprediksi hubungan yang positif antara firm size dengan cash holding (Borici 
dan Kruja, 2016). Penelitian yang dilakukan oleh Abdillah \& Kusumastuti (2014), Mesfin (2016), Kariuki et al.(2015), Bach et al. (2014), Jamil et al. (2016) dan Shabbir et al. (2016), serta Borici \& Kruja (2016) menemukan bahwa firm size memiliki pengaruh positif signifikan pada cash holding.

$\mathrm{H}_{2 . \mathrm{a}}$ : Firm size berpengaruh positif signifikan pada cash holding.

Tingginya peluang investasi yang dimiliki perusahaan menunjukkan semakin tingginya kemampuan perusahaan untuk memperoleh return yang dapat digunakan sebagai cadangan kas. Perusahaan dengan peluang pertumbuhan tinggi akan lebih senang memegang kelebihan aset likuid (Saddour, 2006). Penelitian Semakin tinggi kesempatan tumbuh perusahaan maka akan semaki tinggi jumlah kas yang dipegang perusahaan Opler et al. (1999). Penelitian Kim et al. (2011), Jinkar (2013) serta William \& Fauzi (2013) menunjukkan pengaruh positif signifikan antara growth opportunity denagn cash holding.

$\mathrm{H}_{2 . b}$ : Growth opportunity berpengaruh positif signifikan pada cash holding.

\section{Pengaruh Cash Holding terhadap Nilai Perusahaan}

Cash holding dianggap akan mampu meningkatkan kinerja perusahaan dengan mengurangi biaya pendanaan eksternal serta mampu memberikan nilai tambah dengan pemenuhan peluang investasi, sehingga akan meningkatkan harga saham serta nilai perusahaan. Hal ini mendukung signaling theory, dimana dengan adanya cash holding maka akan memberikan sinyal positif kepada publik tentang kemampuan perusahaan dalam menjaga likuiditas dan mempertahankan serta meningktakan produktivitas yang akan menyebabkan tingginya nilai perusahaan. 
Luh Putu Erma Liestyasih, dan Luh Putu Wiagustini. Pengaruh Firm Size dan Growth...

Penelitian Cao \& Chen (2014), Kerryanto (2015), serta Fanani \& Hendrick (2016) menemukan pengaruh positif signifikan antara cash holding dan nilai perusahaan. $\mathrm{H}_{3}$ : Cash holding berpengaruh positif signifikan pada firm value.

\section{Pengaruh Firm Size dan Growth Opportunity terhadap Nilai Perusahaan melalui Cash Holding}

Perusahaan besar, umumnya telah berada pada tahap maturity dan memiliki kemampuan mempertahankan cash holding yang tinggi, dimana cash holding tersebut nantinya dapat digunakan untuk menghindari terjadinya likuidasi aset, untuk pembiayaan investasi, dibagikan sebagai dividen serta dapat digunakan sebagai cadangan untuk kejadian-kejadian yang tidak terduga di masa depan sehingga investor akan tertarik berinvestasi di perusahaan. Berdasarkan hal ini, maka hipotesis yang dapat diajukan untuk mengetahui pengaruh firm size terhadap nilai perusahaan melalui cash holding.

$\mathrm{H}_{4 . \mathrm{a}}$ : Firm size berpengaruh positif signifikan pada firm value melalui cash holding.

Perusahaan dengan growth opportunity tinggi akan mampu meningkatkan jumlah cash holding yang tinggi di masa depan, dengan cash holding yang semakin tinggi maka kebutuhan pendanaan operasional perusahaan serta investasi akan terpenuhi. Hal ini akan dilihat oleh investor sebagai hal baik bagi pertumbuhan perusahaan di masa depan, sehingga akan mampu meningkatkan nilai pasar perusahaan.

$\mathrm{H}_{4 . \mathrm{b}}$ : Growth opportunity berpengaruh positif signifikan pada firm value melalui cash holding. 


\section{METODE PENELITIAN}

Penelitian ini adalah penelitian asosiatif. Perusahaan sektor Manufaktur di BEI tahun 2013-2016 digunakan sebagai ruang lingkup wilayah penelitian. Data kuantitatif berbentuk laporan keuangan merupakan sumber data pada penelitian ini. Penelitian ini menggunakan variabel eksogen, mediasi dan endogen. Variabel eksogen yaitu, firm size $\left(\mathrm{X}_{1}\right)$ dan growth opportunity $\left(\mathrm{X}_{2}\right)$; variabel mediasi adalah cash holding $\left(\mathrm{Y}_{1}\right)$. Variabel endogen yaitu firm value $\left(\mathrm{Y}_{2}\right)$. Firm size disini diproksikan dengan Ln (Total Aset), growth opportunity dihitung dengan pertumbuhan penjualan, cash holding diproksikan dengan membandingkan antara kas dan setara kas dengan total aset, serta firm value dihitung dengan Tobin's Q.

Populasi yang diteliti merupakan perusahaan sektor Manufaktur yang terdaftar di BEI periode 2013-2016, yang berjumlah 124 perusahaan yang menerbitkan laporan keuangan dari tahun 2013-2016. Sampel diperoleh dengan teknik purposive, dengan kriteria perusahaan yang memiliki pertumbuhan penjualan bernilai positif, sehingga diperoleh sampel sebanyak tiga puluh delapan perusahaan. Metode observasi nonpartisipan digunakan dalam mengumpulkan data penelitian, sedangkan path analysis digunakan sebagai teknik analisis data.

\section{HASIL DAN PEMBAHASAN}

\section{Deskripsi Variabel Penelitian}

Berdasarkan Tabel 1. memperlihatkan nilai terendah (minimum) dari variabel firm size $\left(\mathrm{X}_{1}\right)$ adalah $\mathrm{Rp} 25,64$, sedangkan nilai tertinggi (maksimum) dari variabel firm size $\left(\mathrm{X}_{1}\right)$ adalah $\mathrm{Rp} 32,15$. Variabel growth opportunity $\left(\mathrm{X}_{2}\right)$ memiliki nilai terendah selama periode pengamatan yaitu 0,001 atau 0,1 persen 
Luh Putu Erma Liestyasih, dan Luh Putu Wiagustini. Pengaruh Firm Size dan Growth...

dan peluang pertumbuhan perusahaan tertinggi selama periode pengamatan yaitu 0,476 atau 47,6 persen. Variabel cash holding (Y1) memiliki nilai terendah (minimum) selama periode pengamatan yaitu 0,002 sedangkan nilai cash holding tertinggi (maksimum) yaitu 0,703 . Variabel firm value $\left(\mathrm{Y}_{2}\right)$ memiliki nilai terendah sebesar $(0,294)$ persen sedangkan nilai tertinggi sebesar 18,365 persen.

Tabel 1.

\begin{tabular}{lrrrrr}
\multicolumn{6}{c}{ Hasil Analisis Deskriptif } \\
& N & Minimum & Maximum & Mean & $\begin{array}{c}\text { Std. } \\
\text { Deviation }\end{array}$ \\
\hline SZ & 152 & 25,637 & 32,151 & 28,80963 & 1,51009 \\
GO & 152 & 0,001 & 0,476 & 0,12785 & 0,08875 \\
CH & 152 & 0,002 & 0,703 & 0,11617 & 0,127053 \\
FV & 152 & $-0,294$ & 18,365 & 2,18255 & 3,254012 \\
Valid N & 152 & & & & \\
(listwise) & & & & & \\
\hline \multicolumn{5}{l}{ Sumber: Output SPSS, 2017 }
\end{tabular}

\section{Hasil Uji Asumsi Klasik}

Hasil uji normalitas model pertama dan kedua menunjukkan tingkat signifikansi Sig. (2-tailed) sebesar 0,183 dan 0,140>0,05 maka menunjukkan data berdistribusi secara normal. Pada hasil uji multikolinieritas nilai tolerance masing-masing model pertama dan kedua menunjukkan nilai $>0,1$ dan nilai VIF masing-masing model menunjukkan nilai $<10$ maka dikatakan model penelitian ini bebas dari multikolinieritas. Hasil uji heteroskedastisitas memperlihatkan bahwa keseluruhan nilai signifikansi dari uji heteroskedastisitas $>0,05$, hasil uji model pertama pada variabel firm size $\left(\mathrm{X}_{1}\right)$ memiliki nilai Sig. 0,590 dan growth opporunity $\left(\mathrm{X}_{2}\right)$ memiliki nilai Sig. 0,864 , sedangkan pada model kedua variabel firm size $\left(\mathrm{X}_{1}\right)$ memiliki nilai Sig. 0,201 , growth opporunity $\left(\mathrm{X}_{2}\right)$ memiliki nilai Sig. 0,831, dan cash holding $\left(\mathrm{Y}_{1}\right)$ memiliki nilai Sig. 0,905 maka model penelitian 
bebas dari gejala heteroskedastisitas. Pada uji autokorelasi model pertama memiliki nilai DW sebesar 1,994, maka hasil uji autokorelasinya adalah dU $<$ DW $<4-$ dU yaitu $1,7616<1,994<2,2384$, model kedua memiliki nilai DW sebesar 1,972 dan hasil uji autokorelasinya adalah dU $<$ DW $<4-$ dU yaitu $1,7752<1$, $972<2,2248$, sehingga model pertama dan kedua tidak ada gejala autokorelasi.

Tabel 2.

Hasil Uji Asumsi Klasik

\begin{tabular}{|c|c|c|c|}
\hline \multirow{2}{*}{$\begin{array}{c}\text { Uji Asumsi } \\
\text { Klasik }\end{array}$} & \multicolumn{2}{|c|}{ Hasil Uji } & \multirow{2}{*}{ Keterangan } \\
\hline & Model 1 & Model 2 & \\
\hline Uji Normalitas & $\mathrm{p}(0,183)>0,05$ & $\mathrm{p}(0,140)>0,05$ & $\begin{array}{l}\text { Berdistribusi } \\
\text { normal }\end{array}$ \\
\hline $\begin{array}{l}\text { Uji } \\
\text { Multikolinearitas }\end{array}$ & $\begin{array}{l}\text { Tolerance }(0,995) \\
(0,995)>0,1 \\
\text { VIF }(1,006) \\
(1,006)<10\end{array}$ & $\begin{array}{l}\text { Tolerance }(0,990) ;(0,829) ; \\
(0,835)>0,1 \\
\text { VIF }(1,011) ;(1,207) ;(1,197)< \\
10\end{array}$ & $\begin{array}{l}\text { Tidak ada } \\
\text { multikolinearitas }\end{array}$ \\
\hline $\begin{array}{l}\text { Uji } \\
\text { Heteroskedastisitas }\end{array}$ & $\begin{array}{l}\mathrm{p}(0,590) ;(0,864)> \\
0,05\end{array}$ & $\mathrm{p}(0,201) ;(0,831) ;(905)>0,05$ & $\begin{array}{l}\text { Tidak terjadi } \\
\text { heteroskedastisitas }\end{array}$ \\
\hline Uji Autokorelasi & $\begin{array}{l}1,7616<1,994< \\
2,2384\end{array}$ & $1,7752<1,972<2,2248$ & $\begin{array}{l}\text { Tidak } \\
\text { mengandung } \\
\text { gejala } \\
\text { autokorelasi }\end{array}$ \\
\hline
\end{tabular}

Sumber: Output SPSS, 2017.

\section{Hasil Uji Hipotesis}

Uji hipotesis pada analisis model koefisien jalur terbagi menjadi dua jenis, yaitu uji model pertama dan uji model kedua.

Tabel 3.

Rekapitulasi Output Pengaruh Langsung Model Pertama

\begin{tabular}{lcccc}
\hline \multicolumn{1}{c}{ Variabel } & $\begin{array}{c}\text { Unstandardized } \\
\text { Coefficients }\end{array}$ & $\begin{array}{c}\text { Standardized } \\
\text { Coefficients }\end{array}$ & Nilai t & Signifikansi \\
\hline (constant) & 0,683 & & 4,790 & 0,000 \\
Firm Size & $-0,021$ & $-0,296$ & $-4,151$ & 0,000 \\
Growth Opp & 0,143 & 0,374 & 5,244 & 0,000 \\
F : 24,108 & & & & 0,000 \\
\hline
\end{tabular}

Sumber: Output SPSS, 2017

Dari Tabel 3. besarnya pengaruh langsung pada model pertama yang memperoleh hasil persamaan struktural, yaitu sebagai berikut : 


$$
Y_{1}=-0,296 X_{1}+0,374 X_{2}
$$

Persamaan regresi menunjukkan arah dan besarnya pengaruh variabel eksogen pada variabel endogen:

a) $\quad \beta_{1}=-0,296$ memiliki arti bahwa saat firm size meningkat sebesar $1 \%$ maka cash holding akan menurun 29,6\%.

b) $\quad \beta_{2}=0,374$ memiliki arti bahwa saat growth opportunity meningkat sebesar $1 \%$ maka cash holding akan meningkat 37,4\%.

\section{Tabel 4.}

Rekapitulasi Output Pengaruh Langsung Model Kedua

\begin{tabular}{lcccc}
\hline \multicolumn{1}{c}{ Variabel } & $\begin{array}{c}\text { Unstandardized } \\
\text { Coefficients }\end{array}$ & $\begin{array}{c}\text { Standardized } \\
\text { Coefficients }\end{array}$ & Nilai t & Signifikansi \\
\hline (constant) & $-13,144$ & & $-4,022$ & 0,000 \\
Firm Size & 0,511 & 0,288 & 4,485 & 0,000 \\
Growth Opp & 2,043 & 0,382 & 5,448 & 0,000 \\
Cash Holding & 1,360 & 0,246 & 3,526 & 0,001 \\
F : 32,361 & & & & 0,000 \\
\hline
\end{tabular}

Sumber: Output SPSS, 2017

Tabel 4. menunjukkan besarnya pengaruh langsung pada model kedua dengan memperoleh hasil persamaan struktural, yaitu:

$$
Y_{2}=0,288 X_{1}+0,382 X_{2}+0,246 Y_{1}
$$

Persamaan regresi menunjukkan arah dan besarnya pengaruh variabel eksogen pada variabel endogen, yaitu:

a) $\quad \beta_{1}=0,288$ memiliki arti saat firm size meningkat sebesar $1 \%$ maka firm value akan meningkat $28,8 \%$.

b) $\quad \beta_{2}=0,382$ memiliki arti saat growth opportunity meningkat sebesar $1 \%$ maka firm value akan meningkat $38,2 \%$. 
c) $\quad \beta_{3}=0,246$ memiliki arti saat cash holding meningkat sebesar $1 \%$ maka firm value akan meningkat $24,6 \%$.

\section{Hasil Uji F (Simultan)}

Model pertama menunjukkan nilai $\mathrm{F}$ hitung adalah 24,108 dengan signifikansi $0,000<0,05$ (taraf signifikansi $(\alpha)$ ). Hasil signifikansi menunjukkan firm size serta growth opportunity secara serempak berpengaruh positif signifikan pada cash holding. Pada model kedua terlihat nilai $\mathrm{F}$ hitung adalah 32,361 dengan signifikansi $0,000<0,05$. Hal ini menandakan firm size, growth opportunity, serta cash holding secara serempak memiliki pengaruh positif signifikan pada nilai perusahaan.

\section{Hasil Uji Parsial (t-test)}

Uji Parsial (t-test) dilakukan dengan membandingkan signifikansi variabel eksogen dengan $\alpha=0,05$. Jika tingkat signifikansi $\mathrm{t}<0,05$ maka $\mathrm{H}_{1}$ diterima serta $\mathrm{H}_{0}$ ditolak, sebaliknya bila tingkat signifikansi $\mathrm{t}>0,05$ maka $\mathrm{H}_{1}$ ditolak serta $\mathrm{H}_{0}$ diterima.

a) Nilai signifikansi firm size $\left(\mathrm{X}_{1}\right)$ yaitu $0,000<0,05$ dengan nilai t sebesar 4,485 .

Nilai tersebut memiliki arti bahwa firm size $\left(\mathrm{X}_{1}\right)$ berpengaruh positif signifikan pada nilai perusahaan $\left(\mathrm{Y}_{2}\right)$. Hasil ini menunjukkan bahwa $\mathrm{H}_{0}$ ditolak dan $\mathrm{H}_{1 . \mathrm{a}}$ yang menyatakan terdapat pengaruh positif signifikan antara firm size dengan nilai perusahaan dalam penelitian ini diterima.

b) Nilai signifikansi growth opportunity $\left(\mathrm{X}_{2}\right)$ adalah $0,000<0,05$ dan nilai $\mathrm{t}$ sebesar 5,448. Nilai tersebut memiliki arti bahwa growth opportunity $\left(\mathrm{X}_{2}\right)$ berpengaruh positif signifikan pada nilai perusahaan $\left(\mathrm{Y}_{2}\right)$. Hasil ini menunjukkan bahwa $\mathrm{H}_{0}$ ditolak dan $\mathrm{H}_{1 . \mathrm{b}}$ yang menyatakan terdapat pengaruh 
positif signifikan antara growth opportunity dengan nilai perusahaan dalam penelitian ini diterima.

c) Nilai signifikansi firm size $\left(\mathrm{X}_{1}\right)$ adalah $0,000<0,05$ dan nilai t sebesar $-4,151$. Nilai tersebut memiliki arti bahwa firm size $\left(\mathrm{X}_{1}\right)$ berpengaruh negatif signifikan pada cash holding $\left(\mathrm{Y}_{1}\right)$. Hasil ini menunjukkan bahwa $\mathrm{H}_{0}$ diterima dan $\mathrm{H}_{2 . a}$ yang menyatakan firm size berpengaruh positif signifikan pada cash holding dalam penelitian ini ditolak.

d) Nilai signifikansi growth opportunity $\left(\mathrm{X}_{2}\right)$ adalah $0,000<0,05$ dan nilai $\mathrm{t}$ sebesar 5,244. Nilai tersebut memiliki arti bahwa growth opportunity $\left(\mathrm{X}_{2}\right)$ berpengaruh positif signifikan pada cash holding $\left(\mathrm{Y}_{1}\right)$. Hasil ini menunjukkan bahwa $\mathrm{H}_{0}$ ditolak dan $\mathrm{H}_{2 . \mathrm{b}}$ yang menyatakan terdapat pengaruh positif signifikan antara growth opportunity dengan cash holding dalam penelitian ini diterima.

e) Nilai signifikansi cash holding $\left(\mathrm{Y}_{1}\right)$ adalah $0,001<0,05$ dengan nilai t sebesar 3,526. Nilai tersebut memiliki arti bahwa cash holding $\left(\mathrm{Y}_{1}\right)$ berpengaruh positif signifikan pada nilai perusahaan $\left(\mathrm{Y}_{2}\right)$. Hasil ini memperlihatkan $\mathrm{H}_{0}$ ditolak dan $\mathrm{H}_{3}$ yang menyatakan cash holding berpengaruh positif signifikan pada nilai perusahaan diterima.

\section{Hasil Uji Pengaruh Total}

Uji pengaruh total dilakukan dengan menguji secara gabungan antara pengaruh langsung variabel eksogen dengan firm value serta pengaruh tidak langsung variabel eksogen dengan firm value melalui variabel mediasi yaitu cash 
holding. Berikut adalah rekapitulasi pengaruh langsung, pengaruh tidak langsung, serta pengaruh total.

Tabel 5.

Rekapitulasi Output Pengaruh Langsung, Pengaruh tidak Langsung, dan Pengaruh Total

\begin{tabular}{|c|c|c|c|c|c|c|c|}
\hline & Hubungan & $\begin{array}{l}\text { Pengaruh } \\
\text { langsung }\end{array}$ & $\begin{array}{c}\text { Pengaruh } \\
\text { tidak } \\
\text { langsung }\end{array}$ & $\begin{array}{c}\text { Pengaruh } \\
\text { total }\end{array}$ & Koefisien & Signifikansi & Ket. \\
\hline \multirow{4}{*}{$\begin{array}{c}\text { Model } \\
1\end{array}$} & $\mathrm{SZ}=>\mathrm{FV}$ & 0,288 & - & 0,288 & 0,511 & 0,000 & signifikan \\
\hline & $\mathrm{SZ}=>\mathrm{CH}$ & $-0,296$ & - & $-0,296$ & $-0,021$ & 0,000 & signifikan \\
\hline & $\mathrm{CH}=>\mathrm{FV}$ & 0,246 & - & 0,246 & 1,360 & 0,001 & signifikan \\
\hline & $\mathrm{SZ} \Rightarrow \mathrm{CH} \Rightarrow \mathrm{FV}$ & 0,288 & $-0,073$ & 0,215 & - & - & $\begin{array}{c}\text { tidak } \\
\text { mampu }\end{array}$ \\
\hline \multirow{4}{*}{$\begin{array}{c}\text { Model } \\
2\end{array}$} & $\mathrm{GO} \Rightarrow>\mathrm{FV}$ & 0,382 & - & 0,382 & 2,043 & 0,000 & signifikan \\
\hline & $\mathrm{GO} \Rightarrow \mathrm{CH}$ & 0,374 & - & 0,374 & 0,143 & 0,000 & signifikan \\
\hline & $\mathrm{CH}=>\mathrm{FV}$ & 0,246 & - & 0,246 & 1,360 & 0,001 & signifikan \\
\hline & $\mathrm{GO} \Rightarrow>\mathrm{CH} \Rightarrow \mathrm{FV}$ & 0,382 & 0,092 & 0,474 & - & - & mampu \\
\hline
\end{tabular}

Sumber: Output SPSS, 2017

Berdasarkan Tabel 5. dapat dikatakan cash holding mampu untuk memediasi pengaruh growth opportunity terhadap nilai perusahaan dengan kriteria mediasi sebagian (partial mediation).

\section{Hasil Uji Validitas Model}

Nilai $R_{m}^{2}=0,5441$ atau sebesar $54,41 \%$ memiliki arti variasi dari nilai perusahaan mampu dijelaskan oleh model yang dibentuk, yaitu firm size, growth opportunity, dan cash holding sebesar $54,41 \%$, sisanya sebesar $45,59 \%$ dijelaskan oleh faktor lain di luar model.

\section{Pengaruh Firm Size terhadap Nilai Perusahaan}

Hipotesis pertama yang menyatakan terdapat pengaruh positif signifikan antara firm size dengan firm value dapat diterima. Hasil temuan ini mendukung penelitian Hermuningsih (2012), Hidayah (2014), Putu et al. (2014) dan Novari \& Lestari (2016) yang menemukan firm size berpengaruh positif signifikan pada nilai perusahaan, ini menjelaskan jika perusahaan yang memiliki firm size tinggi 
Luh Putu Erma Liestyasih, dan Luh Putu Wiagustini. Pengaruh Firm Size dan Growth...

akan dengan mudah mendapatkan kepercayaan dari investor dan kreditor karena perusahaan dianggap terlalu besar untuk bangkrut, sehingga perusahaan dengan firm size tinggi relatif lebih mudah dalam meningkatkan nilai perusahaannya. Berdasarkan signaling theory, perusahaan dengan total aset tinggi dapat memberikan signal yang positif kepada investor dan kreditor karena perusahaan dianggap relatif lebih stabil dan memiliki kemampuan yang lebih besar dalam menghasilkan keuntungan.

\section{Pengaruh Growth Opportunity terhadap Nilai Perusahaan}

Hipotesis kedua yang diajukan menyatakan terdapat pengaruh positif signifikan anatra growth opportunity dengan firm value diterima. Perusahaan dengan growth opportunity tinggi akan lebih mampu menarik minat investor untuk berinvestasi pada perusahaan, hal ini terjadi karena growth opportunity akan memberikan peluang bagi investor untuk mendapatkan tingkat pengembalian yang besar dimasa depan. Sesuai dengan signaling theory, growth opportunity yang tinggi akan memberikan sinyal kepada investor maupun kreditur jika perusahaan akan tumbuh di masa depan dan mampu menghasilkan return yang tinggi sehingga investor akan tertarik menanamkan modalnya, yang pada akhirnya mampu meningkatkan harga saham. Hasil ini mendukung penelitian Hermuningsih (2013), Pangulu \& Maski (2015), Tikawati (2016), dan Andawasatya et al. (2017).

\section{Pengaruh Firm Size terhadap Cash holding}

Hipotesis ketiga menyatakan firm size berpengaruh positif signifikan pada cash holding menemukan hasil dengan arah yang berbeda, yaitu ditemukan bahwa 
firm size berpengaruh negatif signifikan pada cash holding. Hasil ini mendukung penelitian Gill \& Shah (2012), Loncan \& Caldeira (2014) serta Hilgen (2015) yang menemukan hubungan negatif signifikan antara firm size dengan cash holding, yang menyiratkan bahwa perusahaan manufaktur yang memiliki skala besar akan menghadapi tingkat kerentanan yang rendah terhadap financial distress sehingga tidak memerlukan jumlah cash holding yang besar. Trade of theory memprediksi hubungan negatif antara ukuran perusahaan dengan cash holding (Borges, 2016). Menurut trade of theory perusahaan akan berusaha menetapkan jumlah cash holding yang optimal, dengan memperhitungkan manfaat serta biaya yang ditimbulkan dari penggunaan cash holding. Semakin besar firm size maka semakin perusahaan berusaha mempertahankan cash holding optimalnya, sebab kesalahan dalam menetapkan cash holding akan berpengaruh terhadap nilai dari perusahaan.

\section{Pengaruh Growth Opportunity terhadap Cash holding}

Hipotesis keempat yang menyatakan terdapat pengaruh positif signifikan antara growth opportunity dengan cash holding dapat diterima. Hasil ini mendukung penelitian Kim et al. (2011), Jinkar (2013) serta William \& Fauzi (2013). Semakin tinggi peluang tumbuh sebuah perusahaan, semakin tinggi pula kesempatan untuk mendapatkan return yang lebih besar, sehingga kemampuan perusahaan untuk mempertahankan kas sebagai pemenuh kebutuhan investasi dimasa depan semakin tinggi. Berdasarkan pecking order theory, perusahaan dengan peluang pertumbuhan besar akan lebih memilih penggunaan sumber dana internal dalam memenuhi kebutuhan investasinya. Perusahaan dengan peluang 
Luh Putu Erma Liestyasih, dan Luh Putu Wiagustini. Pengaruh Firm Size dan Growth...

tumbuh tinggi, akan membutuhkan modal besar untuk investasi, tetapi ketersediaan modal eksternal biasanya sangat rendah dan mahal sehingga untuk mengurangi dilewatkannya kesempatan investasi, perusahaan akan lebih senang memegang kelebihan dari aset likuid.

\section{Pengaruh Cash Holding terhadap Nilai Perusahaan}

Hipotesis kelima yang menyatakan cash holding berpengaruh positif signifikan pada firm value diterima. Hasil ini mendukung temuan Cao \& Chen (2014), Kerryanto (2015), Zahedi et al. (2015), Nhan \& Ha (2016), Fanani \& Hendrick (2016), serta Sutrisno (2017) yang menemukan terdapat pengaruh positif signifikan antara cash holding dengan firm value. Perusahaan manufaktur di Indonesia memegang cash holding dalam jumlah yang tinggi. Cash holding yang tinggi pada perusahaan Manufaktur di Indonesia menunjukkan kelikuiditasan perusahaan. Kemampuan perusahaan manufaktur di Indonesia untuk menjaga tingkat operasional dan kemampuan bertahan dalam keadaan ekonomi yang tidak pasti menunjukkan kinerja perusahaan yang baik. Hal ini akan menarik minat investor untuk berinvestasi di perusahaan, yang akhirnya mampu meningkatkan harga saham yang mencerminkan nilai perusahaan. Ini juga sesuai dengan signaling theory, dimana perusahaan dengan cash holding yang tinggi akan mampu memberikan sinyal positif kepada investor, sehingga akan meningkatkan firm value.

\section{Pengaruh Firm Size pada Nilai Perusahaan melalui Cash Holding}

Cash holding tidak mampu untuk memediasi pengaruh firm size pada firm value, sehingga hipotesis keenam ditolak. Kariuki et al., (2015) menjelaskan jika 
perusahaan dengan firm size tinggi memiliki kemampuan untuk menimbun cash yang lebih besar dibandingkan perusahaan kecil, namun trade off theory meyakini bahwa dengan menjaga tingkat cash holding yang optimal maka perusahaan dapat memaksimalkan nilai perusahaan. Hal ini karena ketika cash holding melebihi tingkat optimalnya maka akan menyebabkan turunnya firm value, sehingga semakin besar firm size semakin berhati-hati perusahaan dalam menentukan tingkat cash holding optimalnya. Hal ini menyebabkan perusahaan akan berusaha menjaga jumlah cash holding-nya tetap optimal.

\section{Pengaruh Growth Opportunity terhadap Nilai Perusahaan melalui Cash Holding}

Hasil penelitian ini menemukan cash holding mampu untuk memediasi pengaruh growth opportunity terhadap firm value. Sesuai dengan hasil olahan data dapat dikatakan bahwa kriteria mediasi dalam penelitian ini adalah mediasi sebagian (partial mediation). Perusahaan dengan pertumbuhan penjualan yang meningkat setiap tahunnya dapat menandakan bahwa perusahaan memiliki kesempatan tumbuh yang tinggi, hal tersebut akan dapat meningkatkan jumlah cash holding perusahaan. Pertumbuhan yang tinggi menggambarkan kemungkinan mendapat laba yang tinggi yang dapat digunakan sebagai cash holding. Perusahaan dengan growth opportunity besar dan cash holding tinggi akan mampu menciptakan kinerja perusahaan yang baik sehingga berakibat terhadap meningkatnya kepercayaan investor. Hal ini akan mengakibatkan meningkatknya harga saham yang menjadi refleksi dari tingginya nilai perusahaan. 


\section{SIMPULAN DAN SARAN}

Berdasarkan hasil pembahasan yang dilakukan, maka disimpulkan bahwa:

1) Firm size ditemukan memiliki pengaruh positif signifikan pada firm value.

2) Growth opportunity berpengaruh positif signifikan dengan firm value.

3) Firm size berpengaruh negatif signifikan pada cash holding.

4) Growth opportunity ditemukan memiliki pengaruh positif signifikan dengan cash holding.

5) Cash holding berpengaruh positif signifikan pada firm value.

6) Cash holding tidak mampu untuk memediasi pengaruh firm size pada firm value.

7) Cash holding mampu memediasi pengaruh growth opportunity pada firm value dengan kriteria mediasi adalah mediasi sebagian (partial mediation).

\section{Saran}

1) Bagi Perusahaan, cash holding yang positif serta mampu memediasi pengaruh growth opportunity dengan nilai perusahaan menunjukkan bahwa perusahaan harus lebih memperhatikan tingkat cash holding. Cash holding yang optimal akan membantu perusahaan dalam memenuhi kesempatan investasi bernilai positif, sehingga mampu meningkatkan kinerja perusahaan. Hal ini akan menyebabkan kepercayaan publik pada perusahaan semakin meningkat. Kedepannya perusahaan agar lebih memperhatikan tingkat cash holding karena cash holding dapat menunjukkan likuiditas perusahaan yang akan berpengaruh terhadap 
pandangan investor terhadap perusahaaan yang akan berakibat pada nilai perusahaan.

2) Mengingat terdapat $45,59 \%$ variasi dari nilai perusahaan yang dapat dijelaskan faktor lain di luar model sehingga untuk penelitian selanjutnya dapat meneliti variabel eksogen lain seperti profitabilitas dan leverage dengan cash holding sebagai variabel mediasi. Penelitian selanjutnya juga dapat memperluas populasi dengan mencakup seluruh perusahaan yang terdaftar di BEI, serta bisa mempergunakan indikator pengukuran lain untuk mengukur growth opportunity seperti menggunakan pertumbuhan aset perusahaan serta IOS (Investment to Earning).

\section{IMPLIKASI PENELITIAN}

\section{Implikasi Teoritis}

1) Berdasarkan hasil penelitian, terlihat firm size menunjukkan pengaruh positif signifikan pada firm value dari perusahaan Manufaktur di BEI tahun 2013-2016. Hasil ini mendukung signalling theory yang menjelaskan semakin besar ukuran perusahaan akan memberikan sinyal positif bagi investor maupun kreditor (Saputra dan Fachrurrozie, 2015).

2) Hasil penelitian terhadap growth opportunity perusahaan menunjukkan pengaruh positif signifikan pada nilai perusahaan Manufaktur di BEI. Hasil ini sejalan dengan temuan Hermuningsih (2013), Pangulu dan Maski (2015), Tikawati (2016), dan Andawasatya et al. (2017).

3) Berdasarkan hasil penelitian, maka terlihat growth opportunity memiliki pengaruh signifikan positif pada cash holding perusahaan Manufaktur di 
BEI tahun 2013-2016. Hasil ini sesuai dengan pecking order theory yang menjelaskan jika perusahaan yang memiliki kesempatan pertumbuhan tinggi akan lebih memilih penggunaan sumber dana internal dalam memenuhi kebutuhan investasinya.

4) Berdasarkan hasil penelitian, didapatkan hasil bahwa cash holding mampu untuk memediasi pengaruh growth opportunity pada nilai perusahaan. Semakin besar growth opportunity yang dilihat dari tingkat penjualan, menandakan bahwa perusahaan akan mampu menambah jumlah cash holding dan dengan cash holding yang dimiliki, perusahaan dapat memberikan kinerja optimal sehingga mampu meningkatkan nilai perusahaan.

\section{Implikasi Praktis}

1) Hasil penelitian ini diharapkan dapat digunakan oleh pihak manajemen perusahaan sebagai acuan bahwa kepemilikan cash holding penting untuk menjaga kelancaran operasi perusahaan serta menjaga nilai perusahaan. Optimalnya cash holding perusahaan diharapkan dapat meningkatkan nilai perusahaan, dengan adanya cash holding untuk pemenuhan investasi dan operasi sehari-hari maka akan mampu meningkatkan kinerja perusahaan sehingga kepercayaan pasar terhadap perusahaan meningkat. Hal ini menyebabkan kepemilikan cash holding yang optimal sangat penting bagi perusahaan.

2) Hasil penelitian ini diharapkan dapat digunakan sebagai acuan bagi investor untuk lebih memperhatikan cash holding dan nilai perusahaan 
sebagai dasar dalam menentukan strategi investasi dalam menanamkan sahamnya di pasar modal. Nilai perusahaan sebaiknya menjadi pertimbangan investor dalam menentukan keputusan investasi, karena nilai perusahaan akan mencerminkan kinerja perusahaan dan memperlihatkan kemampuan perusahaan dalam memaksimalkan kesejahteraan para shareholder-nya.

\section{REFERENSI}

Abdillah, Fajar., dan Kusumastuti, Retno. 2014. Pengaruh Karakteristik Perusahaan dan Board Size Terhadap Corporate Cash Holding. Jurnal FISIP UI: 1-18.

Andawasatya, Rizky, R., Indrawati, Nur, Khusniyah., dan Aisjah, Siti. 2017. The Effect of Growth Opportunity, Profitability, Firm Size to Firm Value through Capital Structure (Study at Manufacturing Companies Listed On the Indonesian Stock Exchange). Imperial Journal of Interdisciplinary Research (IJIR), 3(2): 1887-1894.

Bach, Le, Tuan., Nhan ,Thi, Thanh., dan Dai Pham, Vo, Quang. 2014. Cash Holding and Firm Value: Evidance From Vietnamese Market. The International Conference on Finance And Economics: 344-357.

Bates, Thomas W., Kathleen, M Kahle., Dan Rene, M Stulz. 2009. Why Do U.S. Firms Hold So Much More Cash than They Used To?. The Journal Of Finance, 14(5): 1985-2021.

Borges, Augusto, Rafael, dos, Santos. 2016. Corporate Cash Holdings: An Empirical Investigation Of Portuguese Companies. Dissertation Master in Finance. University of Porto.

Borici, Ardita., dan Alba, Kruja. 2016. Determinants Of Firm's Cash Holding Evidence From Shkodra Region, Albania. International Journal of Economics, Commerce and Management United Kingdom, IV(4): 41-52.

Brigham, Eugene, F., dan Daves, Philip, R. 2010. Intermediate Financial Management. USA: South-Western Cengage Learning.

Cao, Lixian., dan Chen, Chen. 2014. Corporate Cash Holdings And Firm Value Evidence From Chinese Industrial Market. Master Thesis. Simon Fraser University. 
Datta, Mai E, Iskandar., dan Yonghong, Jia. 2012. Cross-Country Analysis Of Secular Cash Trends. Journal of Banking \& Finance, 36: 898-912.

Fanani, Zaenal dan Hendrick S. Yan. 2016. Struktur Kepemilikan Dan Nilai Perusahaan. Jurnal Iqtishadia, 9(1): 99-122.

Gill, Amarjit., dan Shah, Charul. 2012. Determinants Of Corporate Cash holdingss: Evidence From Canada. International Journal Of Economics And Finance, 4(1): 70-79.

Gomes, Marília, de, Sena. 2012. The Financial Determinants Of Corporate Cash Holdings: Evidence From Growing Firms. Dissertation. Universidade Da Beira Interior.

Hardiningsih, Pancawati. 2009. Determinan Nilai Perusahaan. JAI, 5(2): 232-250.

Herijanto, Elleonora, Valencia., dan Budisantosa, A. Totok. 2016. The Factors That Influence Firm's Cash Holdings. http://ejournal.uajy.ac.id/9739/1/JURNAL\%20SUMMARY.pdf (diunduh pada 12 Desember 2016).

Hermuningsih, Sri. 2012. Pengaruh Profitabilitas, Size Terhadap Nilai Perusahaan Dengan Sruktur Modal Sebagai Variabel Intervening. Jurnal Siasat Bisnis, 16.(2): 232-242.

Hermuningsih, Sri. 2013. Pengaruh Profitabilitas, Growth opportunity, Sruktur Modal Terhadap Nilai Perusahaan Pada Perusahaan Publik Di Indonesia. Dalam Buletin Ekonomi Moneter dan Perbankan, 1-22.

Hidayah, Nurul. 2014. The Effect Of Company Characteristic Toward Firm Value In The Property And Real Estate Company In Indonesia Stock Exchange. International Journal of Business, Economics and Law, 5(1): 18.

Hilgen, Maximilian. 2015. The Determinants Of Cash Holdings: Evidence From German Listed Firms. Master Thesis. University of Twente.

Jamil, Sulaman., Anwar, Amna., Afzaal, Naila., Tariq, Adnan., dan Asif, Mohsin. 2016. Determinants of Corporate Cash Holdings: Empirical Analysis of Pakistani Firms. IOSR Journal of Economics and Finance (IOSR-JEF), 7(3): 29-35.

Jinkar, Rebecca, Theresia. 2013. Analisa Faktor-Faktor Penentu Kebijakan Cash holdings Perusahaan Manufaktur di Indonesia. Jurnal FE UI: 1-19.

Kamaludin, dan Rini, Indriani. 2012. Manajemen Keuangan "Konsep Dasar dan Penerapannya”. Edisi Revisi. Bandung : Mandar Maju. 
Kemenperin. 2015. Prospek Industri 2016 Optimisme di Tengah Tantangan. Media Industri Kementrian Perindustrian Republik Indonesia. Jakarta. (online), http://kemenperin.go.id/.

Kerryanto, Fenty. 2015. Pengaruh Mekanisme Corporate Governance, Struktur Kepemilikan, Cash holdings Terhadap Nilai Perusahaan Pada Sektor Manufaktur di Bursa Efek Indonesia Tahun 2010-2013. Jurnal Ilmiah Mahasiswa Surabaya, 4(2): 1-17.

Kim, Sungsin., Ji-Yong, Seo., dan Pando, Sohn. 2011. SMEs' capital structure behavior on cash holdings to Korean financial crisis: The evidence from emerging market. African Journal of Business Management, 5 (34): 1309513115.

Loncan, Tiago, Rodrigues, dan Caldeira, João, Frois. 2014. Capital Structure, Cash holdingss and Firm Value: a Study of Brazilian Listed Firms. R. Cont. Fin. - USP, São Paulo, 25(64): 46-59.

Mesfin, Enyew, Alemaw. 2016. The Factors Affecting Cash Holding Decisions Of Manufacturing Share Companies In Ethiopia. International Journal of Advanced Research in Management and Social Sciences, 5(3): 48-67.

Moeljadi. 2014. Factors Affecting Firm Value: Theoretical Study On Public Manufacturing Firms In Indonesia. South East Asia Journal of Contemporary Business, Economics and Law, 5(2): 6-15.

Nhan, Do, Thi, Thanh., dan Ha, Pham. 2016. Cash Holding, State Ownership and Firm Value: The Case of Vietnam. International Journal of Economics and Financial Issues, 6(6): 110-114.

Novari, Putu, Mikhy., dan Lestari, Putu, Vivi. 2016. Pengaruh Ukuran Perusahaan, Leverage, Dan Profitabilitas Terhadap Nilai Perusahaan Pada Sektor Properti Dan Real Estate. E-Jurnal Manajemen Unud, 5(9): 56715694.

Ogundipe, Lawrencia, Olatunde., Ogundipe, Sunday, Emmanue., dan Ajao, Samuel, Kehinde. 2012. Cash holdings And Firm Characteristics: Evidence From Nigerian Emerging Market. Journal of Business, Economics \& Finance, 2(1): 45-58.

Opler, Tim., Lee, Pinkowitz., Rene, Stulz., dan Rohan, Williamson. 1999. The Determinants And Implications Of Corporate Cash holdings. Journal of Financial Economics, 52: 3-46.

Pamadanu, Dozi. 2013. Pengaruh Profitabilitas Dan Nilai Perusahaan Terhadap Return Saham Pada Perusahaan Automotive And Allied Productsyang Terdaftar Di Bursa Efek Indonesia. Jurnal Manajemen, 2(1): 1-10. 
Pangulu, Agustina, Lastri., dan Maski, Ghozali. 2015. Pengaruh Profitabilitas, Growth Opportunity, Dan Struktur Modal Terhadap Nilai Perusahaan (Studi Pada Perusahaan Perbankan Yang Terdaftar Di Bei Periode 2011- 2013). Jurnal Ilmiah Mahasiswa FEB Universitas Brawijaya, 3(1): 1-13.

Putu, Ni Nyoman, G Martini., Moeljadi., Djumahir., dan Atim, Djazuli. 2014. Factors Affecting Firms Value of Indonesia Public Manufacturing Firms. International Journal of Business and Management Invention, 3(2): 35-44.

Saddour, Khaoula.2006. The Determinants and the Value of Cash holdings: Evidence from French firms. Cahier de Recherche CEREG, 6: 1-33.

Saputra, Hendy, Guntur dan Fachrurrozie. 2015. Determinan Nilai Perusahaan Sektor Property, Real Estate, \& Building Construction Di Bei. Accounting Analysis Journal, 4(2): 1-9.

Setiawati, Rahadi., dan Siti, Rochmah, Ika. 2012. Pengaruh Krisis Keuangan Global Terhadap Kinerja Perusahaan Properti Di Indonesia: Studi Empiris Menggunakan Z-Score Altman. Jurnal Bisnis dan Ekonomi, 3(1): 1-10.

Shabbir, Mohsin., Shujahat, Haider, Hashmi., dan Ghulam, Mujtaba, Chaudhary. 2016. Determinants of corporate cash holdings in Pakistan. International Journal of Organizational Leadership, 5: 50-62.

Sutrisno, Bambang. 2017. Hubungan Cash Holding dan Nilai Perusahaan di Indonesia. Jurnal Dinamika Akuntansi dan Bisnis, 4(1): 45-56.

Sriwardiningsih, Enggal. 2010. Dampak Penularan Krisis Global Terhadap Aliran Investasi Asing Di Indonesia. Journal The WINNERS, 11(2): 130-140.

Suwarno., Ade, Puspito., dan Nurul, Qomariah. 2016. Studi Pengaruh Profitabilitas, Ukuran Perusahaan Dan Peluang Pertumbuhan Terhadap Nilai Perusahaan Pada Perusahaan Telekomunikasi Indonesia. Jurnal Unmuhjember: 1-14.

Tikawati. 2016. Pengaruh Corporate Governance, Growth Opportunity Dan Net Profit Margin (Npm) Terhadap Nilai Perusahaan (Studi Empiris pada Perusahaan Go Public di Bursa Efek Indonesia Tahun 2008-2011). Jurnal Ekonomi dan Bisnis Islam. 02(01): 10-26.

William, dan Fauzi, Syarief. 2013. Analisis Pengaruh Growth Opportunity, Net Working Capital, Dan Cash Conversion Cycle Terhadap Cash holdings Perusahaan Sektor Pertambangan. Jurnal Ekonomi dan Keuangan, 1(2): 7290.

Zahedi, Javad., Talebi, Elahe., dan Aval, Shadi, Laal. 2015. Ownership Concentration, Cash Holding and Firm Value. International Journal of Management, Accounting and Economics, 2(8): 902-912. 